\title{
RELIABILITY OF REUSING THE SENSITIZED LIF THERMOLUMINESCENCE DOSIMETERS
}

\author{
Farag; M. A. ${ }^{*}$, Sadek; A. M. ${ }^{1}$, Shousha; Hany. A. ${ }^{1}$, Al-Hagg; A. A. ${ }^{2}$, Kitis; G. ${ }^{3}$. \\ 1. Ionizing Radiation Metrology Department, National Institute for Standards, El-Haram, P.O. 136, Code \\ No 12211, Giza, Egypt. \\ 2. Physics Department, Faculty of Science, Al-Azhar University of Girl's Branch, 11884, Cairo, Egypt. \\ 3. Aristotle University of Thessaloniki, Nuclear Physics Laboratory, 54124, Thessaloniki, Greece \\ Corresponding Author : maha_6_86@yahoo.com
}

\begin{abstract}
The reliability of reusing the sensitized thermoluminescence (TL) for LiF (TLD-100) dosimeters have been investigated. It has been found that reusing the same sensitized LiF dosimeters may influence the sensitivity of the dosimeters even under the same experimental conditions when the temperature readout range does not include the high-temperature TL signal at $T>505 \mathrm{~K}$. But, if the high-temperature TL signal is included in the temperature readout range, it has been found that the ultra-high temperature TL signal significantly increases with increasing the number of reusing the dosimeters. After almost 7 times of reusing the sensitized dosimeters, the total area under the glow-curve becomes stable and independent of the number of reusing the dosimeters. It has been also found that the TL signal located between the low-temperature TL signal and the ultra-hightemperature TL signal was almost stable over all the number of reusing the dosimeters. For all the lowtemperature peaks, the kinetics parameters of the sensitized LiF dosimeters have not to be influenced by reusing the same dosimeters. However, the activation energy of peak 5 which lies at temperature range (460-500K) has been influenced by the readout temperature range and reusing the dosimeters. The typical value for this glowpeak has been obtained in the case which the high-temperature TL signal has been included in the temperature readout.
\end{abstract}

Keywords: Sensitization; Glow curve analysis; Successive irradiation; Readout temperature.

\section{INTRODUCTION}

Thermoluminescence dosimetry (TLD) is a well-established dosimetric technique with applications in areas such as personnel, environmental and clinical dosimetry. Therefore, considerable research was carried out for a better understanding and improvement of the material characteristics as well as to develop new materials [1]. Nowadays, there is an intensive development of radiation technologies employing high-dose irradiation to modify material properties [2]. It was found that the sensitivity of the TL dosimeters subjected to high dose irradiation followed by the thermal treatment could be enhanced [3]. An often-quoted example is provided by LiF: Mg, Ti in which the sensitivity of TL peak 5 which lies at temperature range $(460-500 \mathrm{~K})$ could be increased by giving the sample a large pre-dose (approximately $10 \mathrm{~Gy}$ ) followed by an anneal at $300^{\circ} \mathrm{C}[3,4]$. Different sensitization studies were also investigated to enhance the sensitivity of the $\operatorname{LiF}$ detectors (e.g., $[5,6,7,8,9,10]$.

Farag et al. [11] have developed sensitization procedure for LiF (TLD-700) dosimeters. It has been found the post-irradiation anneal at $553 \mathrm{~K}\left(280^{\circ} \mathrm{C}\right)$ for $30 \mathrm{~min}$ and a pre-test dose of $2 \mathrm{kGy}$ have increased the sensitivity (total area under the glow-curve) of the dosimeters by a factor of $\sim 35$. However, the dominant factor was increasing the sensitivity of the high-temperature peak (peak-7) by a factor of $\sim 22$. The main idea of the sensitization procedure is to reduce the effect of the deep traps competitors via irradiation and thermal treatments [4]. By suitable pre-irradiation and thermal treatment, the active traps are left empty while the deep trap is left full. In this way, the competitor is removed and subsequent irradiation of the sample leads to an enhanced TL signal [12]. 
In the routine thermoluminescence (TL) dosimetry, the same samples are being reused several times. Therefore, the samples shall be subject to thermal annealing to be reset and hence be reused. However, it was reported that the repeated used of the TL sample may change the sensitivity over the usage period. This is because the repeated use repeatedly places charge into the deep traps and this charge accumulates with each reuse [4].

Another important factor that may influence the sensitivity of the dosimeters is the repeated thermal treatments. In other words, the high-temperature thermal treatments may evacuate the deep traps of the sensitized dosimeters and therefore affects the sensitivity of the dosimeters [13]. The high-temperature thermal treatment could be due to the thermal annealing or the temperature during the readout process. In the work of Farag et al. [11], the thermal annealing for the sensitized $\mathrm{LiF}$ dosimeters has been adjusted to $553 \mathrm{~K}\left(280^{\circ} \mathrm{C}\right)$ which cannot be considered high temperature.

The main aim of the present work is to investigate the stability of the sensitization procedure developed by Farag et al. [11] via two steps:

i. Investigate the effect of the temperature readout range, and

ii. Investigate the effect of the repeated reuse of the same dosimeters on the sensitivity as well as the kinetics parameters of the sensitized LiF dosimeters.

\section{EXPERIMENTAL WORK}

\subsection{Material and methods}

In the current study, TLD-100 dosimeters of size $(3.2 \times 3.2 \times 0.9) \mathrm{mm}^{3}$ have been used. A separate calibrated one-cycle electric oven manufactured by Fisher Scientific Company with an accuracy of $\pm 1{ }^{\circ} \mathrm{C}$ has been used for the thermal treatments. The irradiation processes have been performed using a Co-60 gamma source delivering a dose rate of $1.23 \mathrm{~Gy} \mathrm{~min}^{-1}$ The readout process has been conducted using Harshaw-3500 manual reader with a linear rate of $2^{\circ} \mathrm{C} \mathrm{s}^{-1}$ with different readout temperature zones.

\subsection{Investigate the effect of the temperature readout range}

In order to investigate the influence of the temperature readout range on the stability of the sensitized LiF dosimeters, the following experimental procedures have been followed

1. The TLD-100 dosimeters have been subjected to the sensitization procedure [11].

2. The sensitized detectors have been subjected to a 0.5 Gy test dose.

3. The dosimeters have been divided into five groups G1 $-\Gamma 5$. The temperature readout range of each group is described in Table 1.

Table 1. The temperature readout range applied to the sensitized TL dosimeters.

\begin{tabular}{|c|c|}
\hline Group Number & $\begin{array}{c}\text { Readout Temperature } \\
\text { Zone (K) }\end{array}$ \\
\hline G1 & $323-553$ \\
\hline G2 & $323-573$ \\
\hline G3 & $323-593$ \\
\hline G4 & $323-613$ \\
\hline G5 & $323-633$ \\
\hline
\end{tabular}

\subsection{Investigate the effect of the repeated use}


The above experimental procedures have been repeated 10 times using the same dosimeters for each readout temperature range (presented in Table 1) to investigate the effect of the repeated use.

\section{GLOW-CURVE DECONVOLUTION ANALYSIS}

In the current study, there was a need to calculate the area under certain components of the glow curves. Indeed, the peak height determined from the experimental glow-curve can be also used. However, this method, especially in the present study, may not be appropriate due to the complexity of the glow-curves (as presented in Fig.5). In addition to the high fluctuation in the results reported by this method [14]. The alternative method is using the routine glow-curve deconvolution analysis by fitting the glow-curve with a mathematical TL model. In the current study, the general-order kinetics (GOK) model has been employed in the deconvolution analysis process. The mathematical representation of this model is given by [15];

$\mathrm{I}(\mathrm{T})=\mathrm{I}_{\mathrm{m}}(\mathrm{b})^{\frac{\mathrm{b}}{b-1}} \exp \left(\frac{\mathrm{E}}{\mathrm{kT}} \frac{\mathrm{T}-\mathrm{T}_{\mathrm{m}}}{\mathrm{T}_{\mathrm{m}}}\right)\left[(\mathrm{b}-1)(1-\Delta) \frac{\mathrm{T}^{2}}{\mathrm{~T}_{\mathrm{m}}^{2}} \exp \left(\frac{\mathrm{E}}{\mathrm{kT}} \frac{\mathrm{T}-\mathrm{T}_{\mathrm{m}}}{\mathrm{T}_{\mathrm{m}}}\right)+\mathrm{Z}_{\mathrm{m}}\right]^{-\frac{\mathrm{b}}{\mathrm{b}-1}}$

Where $\mathrm{I}_{m}$ and $\mathrm{T}_{m}(\mathrm{~K})$ are the peak maximum and peak maximum position, respectively, $\mathrm{E}(\mathrm{eV})$ is the activation energy, $\mathrm{b}$ is the order of kinetics which changes from $\sim 1$ to 2 as the glow-peak changes from the first- to the second-order kinetics with and $\Delta=2 \mathrm{kT} / \mathrm{E}, \Delta_{m}=2 \mathrm{kT}_{m} / \mathrm{E}$ and $\mathrm{Z}_{m}=1+(b-1) \Delta_{m}$. The advantage of using this equation is that this expression uses the peak maximum and the peak maximum position in which their initial values can be determined from the experimental glow-curve.

The fitting process has been performed using the 'trust-region' optimization algorithm [16] via the MATLAB package. This algorithm is a simple yet powerful concept optimization. It can solve difficult non-linear problems more efficiently than the other algorithms and it represents an improvement over the popular Levenberg-Marquardt algorithm [17]. In this algorithm, the 'starting value' and/or lower and upper 'limits' of the unknown parameters can be set. This algorithm was used in the TL glow-curve analysis for different applications [18, 19, 20, 21, 22, 23] including the analysis of complicated and overlapping glow-peaks. The quality of the fitting process has been assessed using the Figure of Merit (FOM) in the work of Balian and Eddy [24]

$\operatorname{FOM}(\%)=\sum_{\mathrm{j}_{\mathrm{i}}}^{\mathrm{j}_{\mathrm{f}}} \frac{\left|y_{\mathrm{i}}-\mathrm{y}\left(\mathrm{x}_{\mathrm{i}}\right)\right|}{\mathrm{A}} \times 100$

Where FOM is the figure of merit, $\mathrm{j}_{\mathrm{i}}$ is the first channel in the region of interest, $\mathrm{j}_{\mathrm{f}}$ is the last channel in the region of interest, $y_{i}$ is the information content of channel $j, y\left(x_{i}\right)$ is the value of the fitting function in channel $\mathrm{j}$, and $\mathrm{A}$ is the integral of the fitted glow-peak in the region of interest. In the current work, most of FOM values did not exceed $2 \%$.

Nevertheless, in some complicated cases, where the deconvolution analysis is meaningless, there is a simple integration of the TL signal between two predetermined temperatures has been used to compute the area under the desired TL signal region. This method has been used, especially, to compute the area under the high-temperature TL region because of the complexity of this region and non-universal agreement on the deconvolution procedures of this region [25, 23].

\section{RESULTS AND DISCUSSION}

\subsection{Influence of temperature readout range on the glow-curve of the sensitized LiF dosimeters}

In the current study, the dosimeters have been subjected to the same experimental conditions but with different temperature readout ranges (Table 1). The glow-curves of the first and last groups G1 
and G5 are presented in Fig.1. The typical glow-curve of LiF dosimeter in case of gamma irradiation consists of four low-temperature glow-peaks (2-5) with the main dosimetric peak 5 which is the dominant TL signal in the dosimetric applications [26]. The high-temperature TL signal (HTTL) in $\mathrm{LiF}$ dosimeters is the TL signal located in the temperature region of $[\sim 505-\sim 550) \mathrm{K}$ as illustrated in Fig.1. The analysis of this TL signal was discussed in the work of Horowitz and Yossian [25]. Unusual ultra-HTTL signal has been observed for the glow-curves of sensitized LiF dosimeters recorded with temperature readout range of [323-633]K (Fig.1). This signal has been reported in the work of Farag et al. [11] and was attributed to the effect of the sensitization process subjected to the LiF dosimeters. The area under the low-temperature peaks and the HTTL signal have been calculated using the curve-integral method. The area under the ultra-HTTL could not be included because this signal has been observed only at the [323-633]K temperature readout range.

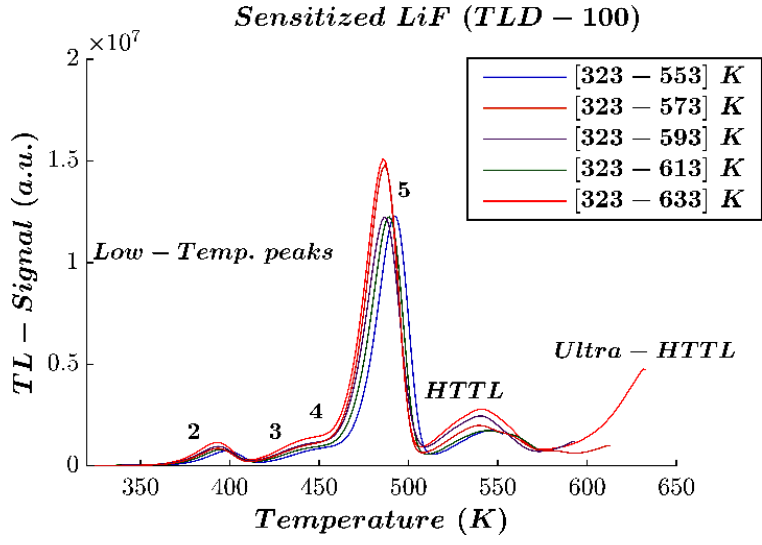

Fig. 1. Effect of different temperature readout ranges on sensitized TLD-100 dosimeters.

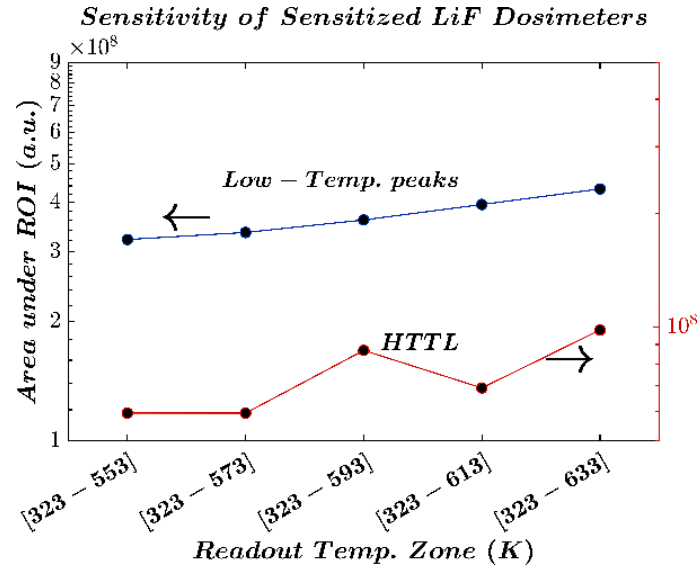

Fig. 2. The area under the low-temperature peaks and the HTTL as a function of the readout temperature zone.

The glow-curves presented in Fig.1 and the analysis results in Fig.2 imply that changing the temperature readout range has no significant changes neither on the sensitivity nor on the shape of the glow-curves. Actually, this was expected because there is no strong interaction between the lowtemperature and the high-temperature peaks during the thermal stage. Of course, the interactions have been already taken place during the "irradiation stage" in which the capacity and the trapping probabilities are the dominant factors.

\subsection{Reliability of reusing the sensitized LiF dosimeters}

\subsubsection{Effect on the TL glow-curve}

In the TL routine dosimetry work, the same dosimeters are used many times. For this reason, the dosimeters should be subjected to certain thermal annealing conditions to reset the dosimeters. It is believed that after the thermal annealing process, all the information due to the previous irradiation process were erased. However, it was reported that reusing the same dosimeters several times may have influenced the sensitivity of the dosimeters even with applying the recommended thermal annealing treatment [27].

In the work of Farag et al. [11], the developed sensitization procedure is mainly based on reducing the competition effect of the deep traps on the active traps. This could be achieved via two steps; the first step is to fill these deep traps with electrons until approaching the saturation level. While the second step is to use the appropriate thermal treatments so that the trapped electrons in the deep traps cannot be released. However, the influence of reusing the dosimeters several times on their sensitivity has not been addressed. In the current section, the effect of reusing the sensitized $\mathrm{LiF}$ dosimeters has been investigated throughout the different ranges of the temperature readout. The same 
experiment carried out in section 4.1 has been repeated 10 times for each temperature readout. As examples, the glow-curves in cases of the $[323-553] \mathrm{K}$ and $[323-633] \mathrm{K}$ temperature readout ranges are illustrated in Fig.3.
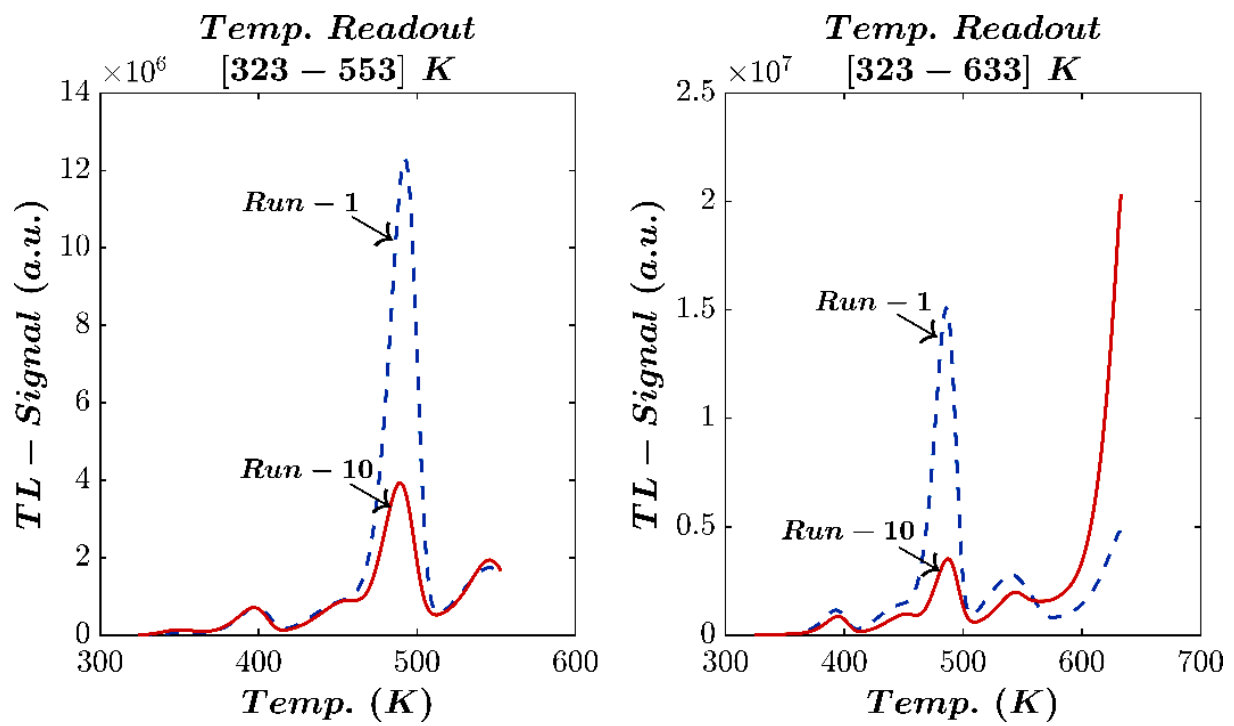

Fig. 3. An example of the glow curves on the influence of re-use the sensitized dosimeters for run1 and run-10 in cases of the $[323-553] \mathrm{K}$ and $[323-633] \mathrm{K}$ temperature readout ranges.

Regardless of the change in the sensitivity of the TL signal, the shape of the glow-curve and the position of the glow-peak components have not been changed. However, in case of the [323-633]K temperature readout range, the ultra-HTTL signal has become the dominant signal in the glow-curve.

\subsubsection{Effect on the TL sensitivity}

It is obvious from Fig. 3 that reusing the same dosimeters several times have caused a dramatic effect on the sensitivity of the dosimeters. The main dosimetric peak 5 component has significantly decreased as the number of reusing the dosimeters increased. Fig. 4 presents the total area under the glow-curves recorded as the number of reusing the dosimeters increase.

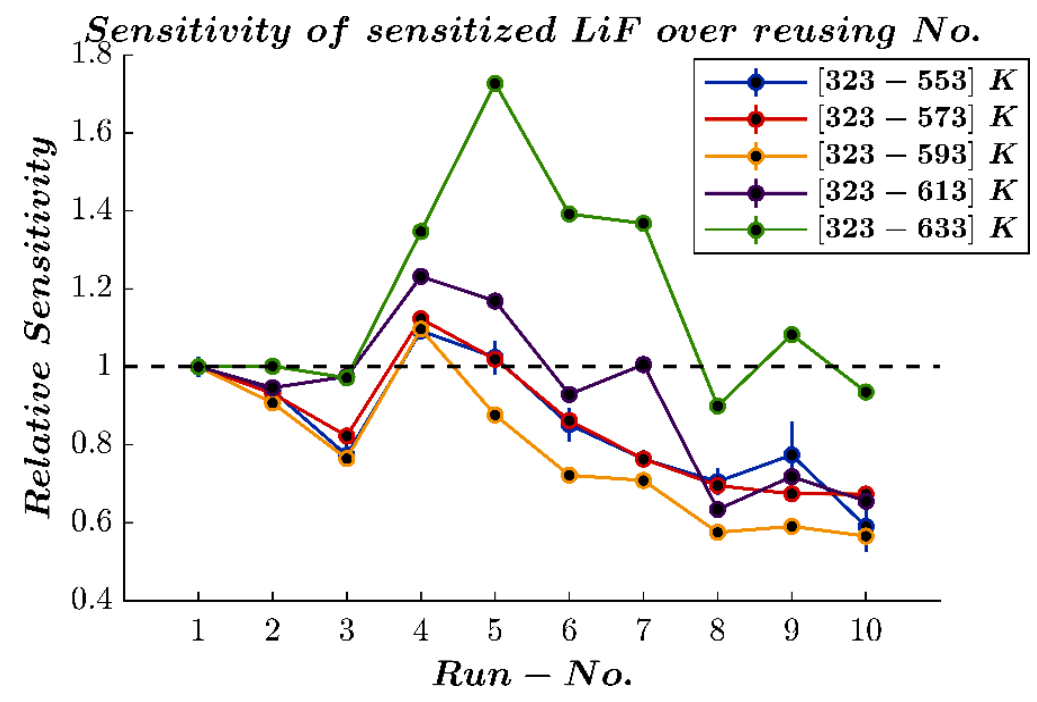

Fig. 4. The sensitivity of sensitized LiF dosimeters as a function of the number of reusing the dosimeters.

After reusing the dosimeters 10 times, the sensitivity of the dosimeters was decreased by a factor $\sim 0.6$ in all the cases, except in the case of $[323-633] \mathrm{K}$ temperature readout range. In this case, after 
reusing the dosimeters 10 times, the sensitivity of the dosimeters remained almost the same. However, an abrupt change has been observed in the sensitivity of the dosimeters when repeating using the dosimeters $4-7$ times. To investigate this behavior, the glow-curves have been deconvoluted as illustrated in Fig.5.

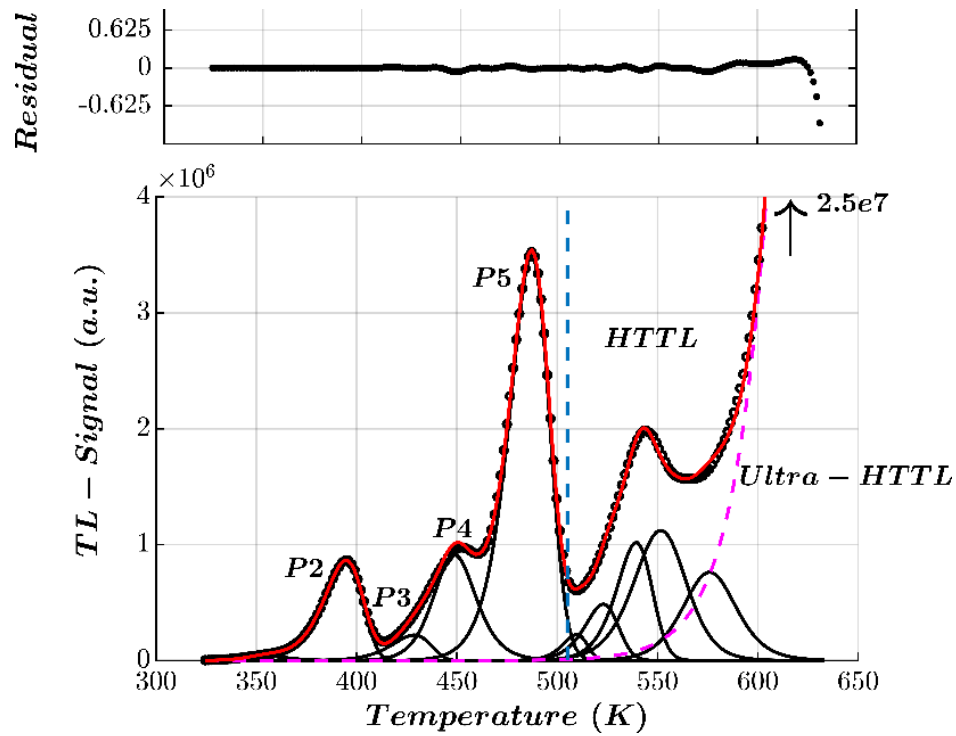

Fig. 5. An example of the deconvolution process conducted to the glow-curves of sensitized LiF dosimeters for reusing run-10 in case of the $[323-633] \mathrm{K}$ temperature readout range.

The low-temperature TL signal has been deconvoluted into the usual four low-temperature peaks (2-5). The HTTL signal has been deconvoluted into 5 components to approach the best goodness-offit. In fact, there is no unique solution to the analysis of the HTTL. Bos et al. [28] and Perks and Marshall [29] deconvoluted the HTTL into six and seven components, respectively. While Horowitz et al. [30] and Horowitz et al. [31] deconvoluted the HTTL into seven peaks. However, Sadek et al. [23] have deconvoluted the HTTL of LiF dosimeters irradiated with Alpha particles into 3 glowpeaks. Indeed, the aim in the current section is neither to address the deconvolution solution of this portion nor to evaluate the kinetics parameters of its component but rather to compute the sensitivity (i.e. the area under) this portion and separate it from the ultra-HTTL signal. Therefore, the area under this HTTL signal has been computed as the summation of the area under the 5 deconvoluted glowpeak. Moreover, an exponential function has been used to compute the area under the ultra-HTTL signal. The results are presented in Fig.6.
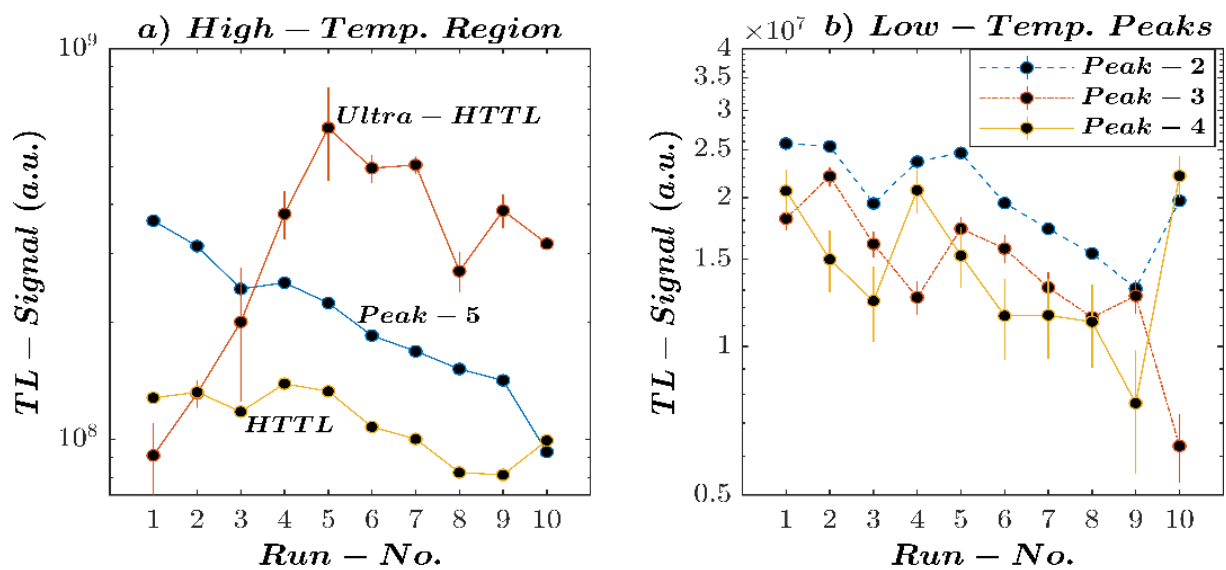

Fig. 6. The sensitivity of low-temperature peaks, high-temperature TL signal HTTL, and ultra-high temperature TL (Ultra-HTTL) in case of the [323- 633] $\mathrm{K}$ temperature readout range as a function of repeatability number. 
It is obvious from Fig.6a that the area under peak 5 is gradually decreasing with increasing the number of reusing the dosimeters. This observation has been also reported for the glow-peaks 2,3 and 4 (Fig.6b). While a significant increase in the area under the ultra-HTTL portion has been observed as the number of reusing the dosimeters increased. This explains the increase in the total area observed in Fig.5 and it also implies that the area under this portion is dominant. However, after reusing the dosimeters 7 times, the sensitivity of the ultra-HTTL portion becomes almost stable.

It was proposed that the glow-peak 10 located at $\sim 673 \mathrm{~K}$ works as a competitor for the glow-peak 5 [4]. The maximum of the temperature readout range in the current study has been set to $633 \mathrm{~K}$. The successful reusing the dosimeters with temperature readout approaching this degree would evacuate some of the electrons trapped in this competitor, and hence, increasing the competition effect on peak 5. This may explain the decreasing in the TL signal of this peak and increasing the TL signal of the ultra-HTTL signal. After a certain reusing number, the rate of decreasing the TL signal of the lowtemperature peaks is equivalent to the rate of increasing the ultra-HTTL signal, and thereby, the total area under the whole glow-curve appears stable.

It is worthwhile to mention that the area under HTTL was almost stable over increasing the reusing number. This may refer to the importance of this signal in the field of TL dosimetry. However, the complex overlapping of this signal with the neighbor signals and the non-unique deconvolution solution for this signal always restrict the using of this signal in the TL dosimetry. Therefore, one may state that the main conclusion of this section is that the total area under the glowcurve of sensitized dosimeters can be used as a dosimetric signal after reusing the dosimeters at least 7 times to approach the stability level.

\subsection{Effect on the kinetic parameters}

The influence of reusing the same dosimeters on the kinetics parameters has been addressed in the present section. The peak position and the activation energy values obtained for the glow-curves of sensitized LiF dosimeters readout using temperature range of [323-633] $\mathrm{K}$ for 10 times are presented in Fig.7.
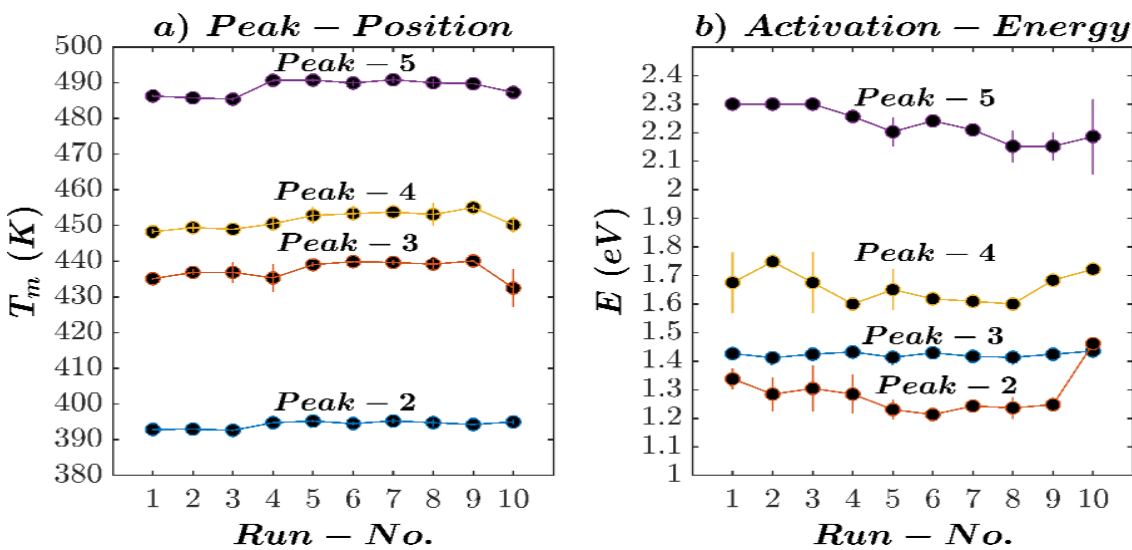

Fig. 7. Peak Position and activation energy values for the low-temperature glow-peaks of sensitized LiF dosimeters readout under the same temperature readout range [323-633] $\mathrm{K}$ for 10 times.

The kinetics parameters of the low-temperature peaks have not been changed with increasing the reusing number. This was expected since there was no change in the shape or the position of the glowpeaks and therefore, the kinetics parameters have not been changed. However, the high activation energy for peak 5 has been obtained. The typical range of the activation energy values of peak 5 is [2.02-2.17] eV [28]. However, the values in the range [2.0-2.3] eV were considered high activation energy values for peak 5 [32]. Indeed, the high activation energy value observed for peak 5 have been reported by Farag et al. [11] and were attributed to the sensitization process. In other words, this high value is not due to reusing the dosimeters but rather due to the sensitization process. It is to be noted 
that this observation has been also reported for all the readout temperature ranges performed in the current study.

The activation energy and the other kinetics parameters for the low-temperature glow-peaks have not been influenced by changing the temperature readout range (Fig.8). This was expected because it has been already discussed that including the high-temperature TL signal in the temperature readout range has not influenced the low-temperature glow-peaks.

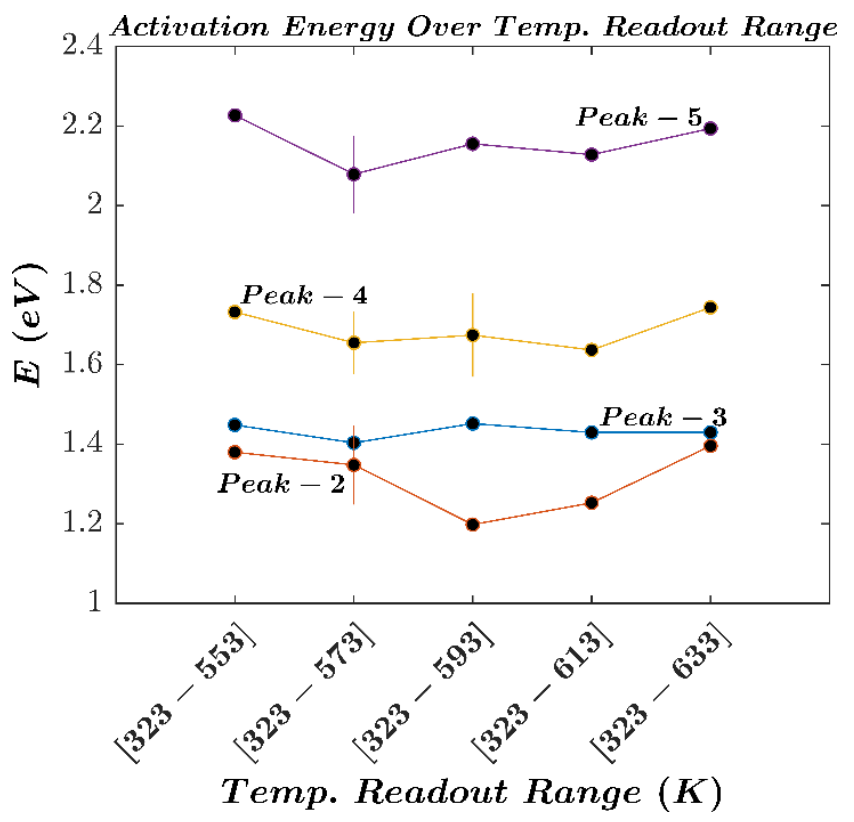

Fig. 8. The activation energy values of the low-temperature peaks throughout the temperature readout ranges for reusing run-10.

The kinetics parameters reported for the low-temperature peaks are the typical values reported in the literature $[28,25,33]$. It implies that the competitor deep traps may influence the sensitivity of the glow-peaks but not their kinetics parameters. This conclusion has been recently reported by Sadek and Kitis [34] using theoretical simulation via interactive phenological TL models.

\section{CONCLUSIONS}

- In the case of [323 - 553] $\mathrm{K}$ temperature readout range, the main dosimetric peak 5 has become the dominant TL signal in the glow-curve, while in case of the [323-633]K temperature readout range, the ultra-HTTL signal has become the dominant TL signal in the glow-curve.

- After reusing the dosimeters 10 times, the sensitivity in the case of the total area of the dosimeters was decreased by a factor $\sim 0.6$ in all the cases of different temperature readout, except in the case of [323-633]K temperature readout range remained almost the same.

- The low-temperature signals decrease while the ultra-high-temperature signals increase with reusing the dosimeters several times.

- After reusing the sensitized dosimeters at least 7 times, the total area under the glow-curve becomes almost stable and reliable for use in the TL dosimetry.

- Therefore, adjusting the temperature readout range approaching this degree $(\sim 633) \mathrm{K}$ to include the high-temperature TL signals is recommended for the sensitized LiF dosimeters.

- The high-temperature TL signal located at the temperature range of [323 - 553] K, namely peaks 7 and 8 , are stable over reusing the same dosimeters several times. 
- The kinetics parameters, the peak position, and the shape of the glow curve for the lowtemperature peaks have neither heen influenced by changing the temperature readout range nor reusing the dosimeters several times.

- High activation energy values for peak 5 have been observed. These high values are neither because of reusing the dosimeters several times nor changing the temperature readout range but rather because of the sensitization process.

\section{REFERENCES}

[1] Bos A J J. High sensitivity thermoluminescence dosimetry. Nucl. Instrum and Meth in Phys. Res. B. 2001; (184): 3-28,

[2] Kortov V, Ustyantsev Yu. Advantages and challenges of high-dose thermoluminescent detectors. Radiat. Meas. 2013; (56): 299-302.

[3] Hwang F S W. Supralinearity and sensitization of thermoluminescent phosphor lithium fluoride. J. Phys. D: Appl. Phys. 1971; (4):598-607.

[4] Chen R, McKeever S W S. Theory of thermoluminescence and related phenomena. 1997, World Scientific Publishing: Singapore.

[5] Marrone M J, Attix F H. Damage effect in CaF2: Mn and LiF thermoluminescent dosimeters. In Health Physics, Northern Ireland, Health Physics Press. 1964; (10):431-436.

[6] Cameron J R, De Werd L A, Wanger J, Wilson C, Doppke K, Zimmerman D W. Symp. on solid-state and chemical radiation dosimetry in medicine and biology. 1966; SM-78/21: (Vienna, IAEA).

[7] Jain V K, Kathuria S P, Ganguly A K. Radiation damage in thermoluminescent LiF TLD-phosphor. J. Phys. C: Solid State Phys. 1975; (8): 2191-2197.

[8] Bhatt B C, Lakshmanan A R, Shinde S S, Bhatt R C. Radiation damage in LiF: Mg, Ti and CaSO4: Dy TLD phosphors. Radiat. Prot. Dosim. 1988; 25(1): 37-41.

[9] Cai G, Wang S, Zhang J. Radiation damage and recovery of LiF: Mg, Ti TLD at the dose of $10^{6}$ Gy $\gamma$-rays. Phys. Stat. Sol. (a). 1990; (121): 57-61.

[10] Bilski P, Obryk B, Stuglik Z. Behavior of LiF: Mg, Cu, P and LiF: Mg, Ti thermoluminescent detectors for electron doses up to 1 MGy. Radiat. Meas. 2010; (45): 576-578.

[11] Farag M A, Sadek A M, Shousha Hany A, El-Hagg A A, Atta M R, Kitis G. Radiation damage and sensitization effects on thermoluminescence of LiF: Mg, Ti (TLD-700). Nucl. Instrum and Meth in Phys. Res. B. 2017; (407): 180-190.

[12] McKeever S W S. $5.5 \mathrm{eV}$ optical absorption, supralinearity, and sensitization of thermoluminescence in LiF TLD-100. J. Appl. Phys. 1990; 68(2): 724-731.

[13] Horowtiz Y S. LiF: Mg, Ti versus LiF: Mg, Cu, P: The competition heats up. Radiat. Prot. Dosim. 1993; (47): 135-141.

[14] Horowtiz Y S, Moscovitch M. Highlights and pitfalls of 20 years of application of computerized glow curve analysis to thermoluminescence research and dosimetry. Radiat. Prot. Dosim. 2012; 153(1): 1-22.

[15] Kitis G, Gómez-Ros J M, Tuyn J W N. Thermoluminescence glow-curve deconvolution functions for first, second and general orders of kinetics. J. Phys. D: Appl. Phys. 1998; (31): 2636-2641.

[16] Moré J J, Sorensen D C. Computing a trust region step. SIAM J. Sci. Stat. Comput. 1983; 4 (3): 553-572.

[17] Mathworks, MATLAB Curve Fitting Toolbox: User's Guide, USA: The MathWorks, Inc., 2004.

[18] Sadek A M. Test of the accuracy of the computerized glow curve deconvolution algorithm for the analysis of thermoluminescence glow curves. Nucl. Instrum and Meth in Phys. Res. A. 2013; (712): 56-61. 
[19] Sadek A M, Eissa H M, Basha A M, Kitis G. Resolving the limitation of the peak fitting and peak shape methods in the determination of the activation energy of thermoluminescence glow peaks. J. Lumin. 2014b; (146): 418-423.

[20] Sadek A M, Eissa H M, Basha A M, Kitis G. Properties of the thermoluminescence glow peaks simulated by the interactive multiple-trap system (IMTS) model. Phys. Stat. Sol. (B). 2014a; (252): 721-729.

[21] Sadek A M, Khamis F, Polymeris G S, Carinou E, Kitis G. Similarities and differences between two different types of the thermoluminescence dosimeters belonging to the LiF family. Phys. Stat. Sol. (C).2016; 14(1-2):1-10 / DOI 101002/PSSC.201600220.

[22] Sadek A M, Kitis G. A critical look at the kinetic parameter values used in simulating the thermoluminescence glow-curve. J. Lumin. 2017b; (183): 533-541.

[23] Sadek A M, Hassan M M, Esmat E, Eissa H M. A new approach to the analysis of thermoluminescence glow-curve of TLD-600 dosimeters following Am-241 alpha particles irradiation. Radiat. Prot. Dosim. 2017a; 178 (3): 260-271.

[24] Balian H G, Eddy N W. Figure-of-merit (FOM), an improved criterion over the normalized Chi-squared test for assessing goodness-of-fit of Gamma-ray spectral peaks. Nucl. Instrum and Meth in Phys. Res. 1977; (145): 389-395.

[25] Horowitz Y S, Yossian D. Computerized glow curve deconvolution: Application to thermoluminescence dosimetry. Radiat. Prot. Dosim. 1995; (60): 1-114.

[26] Yossian D, Horowitz Y S. Computerized glow curve deconvolution applied to the analysis of the kinetics of peak 5 in LiF: Mg, Ti. J. Phys. D: Appl. Phys. 1995; (28): 1495-1508.

[27] Bakshi A K, Pradhan A S, Srivastava K, Kolambe D H. New parameters of annealing and re-use of TLDs based on CaSO4: Dy phosphor. Radiat. Prot. Dosim. 2002; (100): 293-296.

[28] Bos A J J, Piters T M, Gómez-Ros J M, Delgado A. An intercomparison of glow curve analysis computer programs: II. Measured glow curves. Radiat. Prot. Dosim. 1994; (51):257-264.

[29] Perks C A,Marshall M. Techniques for thermoluminescence glow curve analysis. Radiat. Prot. Dosim. 1991; (38): 261-269.

[30] Horowitz Y S, Satinger D, Yossian D, Brandan M E, Buenfill A E, Gamboa-deBuen I and et al. Ionization density effects in the thermoluminescence of TLD-100: computerized Tm-Tstop glow curve analysis. Radiat. Prot. Dosim. 1999; (48): 239-242.

[31] Horowitz Y S, Satinger D, Fuks E, Oster L, Podpalov L. On the use of LiF: Mg, Ti thermoluminescence dosemeters in space - A critical review. Radiat. Prot. Dosim. 2003; (106): 7-24.

[32] Yossian D, Mahajna S, Shachar B.B, Horowitz Y S. Re-investigation of the kinetic trapping parameters of peak 5 in TLD-100 via "prompt" and "residual" isothermal decay. Radiat. Prot. Dosim. 1993; (47): 129133.

[33] Sadek A M, Eissa H M, Basha A M, Carinou E, Askounis P, Kitis G. The deconvolution of thermoluminescence glow-curves using general expressions derived from the one trap-one recombination (OTOR) level model. Appl. Radiat. Isot. 2015; (95): 214-221.

[34] Sadek A M, Kitis G. Impact of non-fulfillment of the superposition principle on the analysis of thermoluminescence glow-curve. Radiat. Meas. 2018; (116): 14-23. 
الملخص العربى

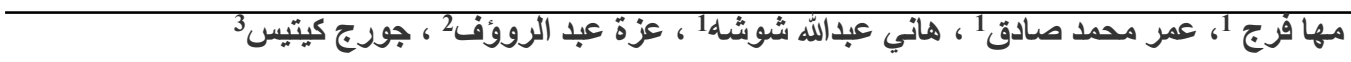

يعتبر قياس الجرعات الأثـعاعية عن طريـق كواثـف الـوميض الحـرارى باسـتخدام مـادة الليثيوم فلور ايد

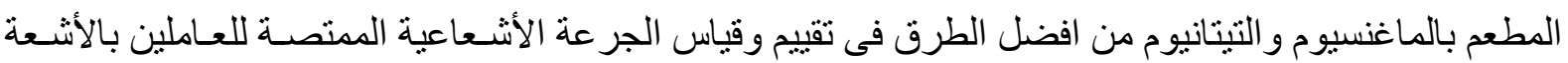
المؤينة . مطعم بـ

لذللك لوحظ إجر اء العديد من الأبحاث لتحسين وفهم خصـائص تلك المـواد المسـتخدمة فـى قيـاس الجر عـات

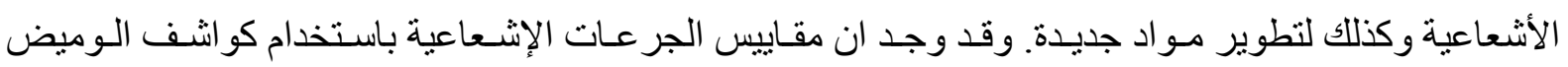

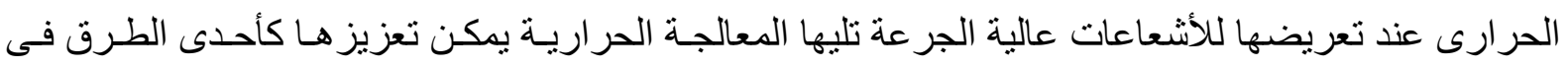

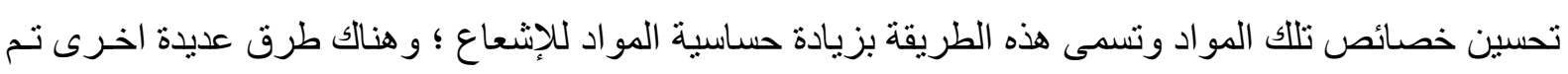
تطبيقها لتعزيز وزيادة حساسية مقاييس الجر عة باستخدام (TLD-10)

وقد قام (11) بتطوير إجر اء لتحسين حساسية مقياس الجر عة لمادة (TLD-10)

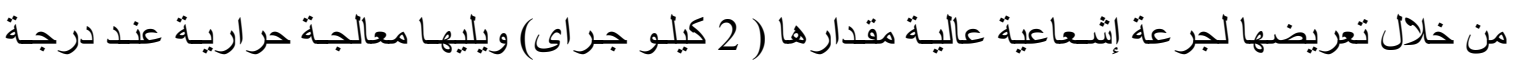
حر ارة عالية مقدار ها 553 كلفن لمـدة (30 دقيقـة) وهذا الإجـر اء أدى إلى زيــادة فـى عامـل الحساسية (S/So)

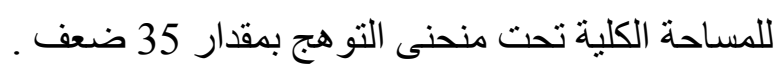
و أيضـا زيادة لعامل الحساسية للقمة السابعة التى تقع فى مدى نطـاق القيم العاليـة لدرجات الحـر ارة لمنحنى التوهج الحر ارى بمقدار 22. و الهـف الأساسى لإجر اء زيادة الحساسـية لمقاييس TLD بهذه الطريقـة هـو تقليـل تـأثنير المصـايد العميقـة

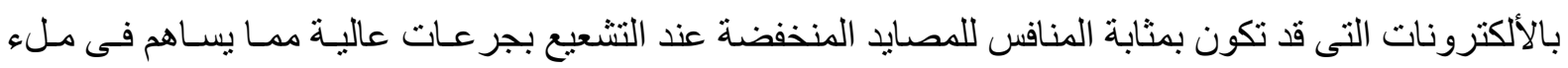
المصايد النشطة لذلك عند التشعيع اللاحق يتم مله المصايد النشطة دون التدخل فى المنافسة مع المصـايد العميقـة و هذا الإجر اء يزيد من الحساسية ويعمل على توسيع منطقة النطاق الخطى وبالتالى إذا كان التشعيع الأول للعينات

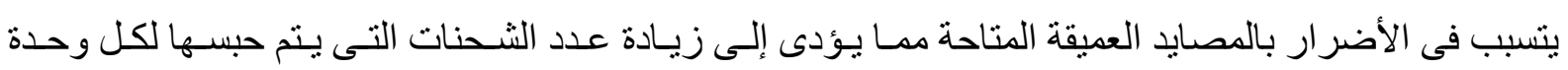
تعريض فى المصايد النشطة وهو ما يهذف إليه مما يؤدى إلى زيادة فى حساسية العينات.

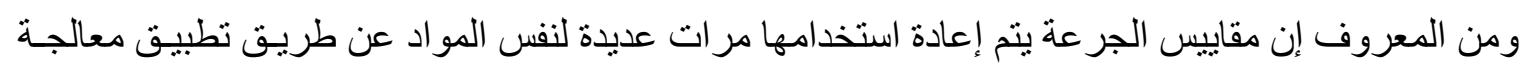
حر ارية لتفريغها من جميع الأكترونات الناتج من التعريض للجر عات الأشعاعية ولكن من أضر ار تلك الأستخدام

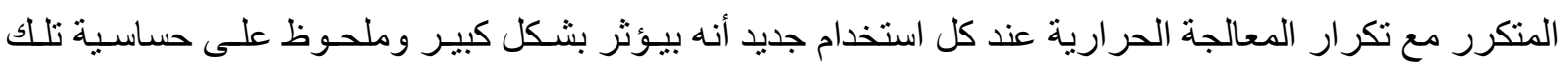

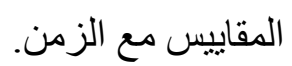
لذلك يقوم تللك البحث بدر اسة موثوقية تأثثر الأستخدام المتكرر عدة مرات مع اختلاف مدى النطاق الحرارى

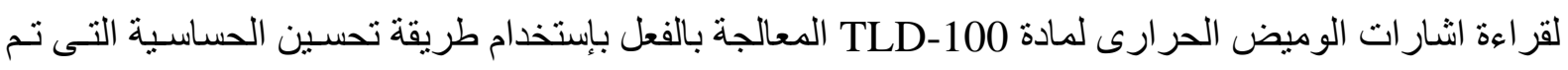
ذكر ها من قبل حيث تتم القر اءة باستخدام جهاز الوميض الحر ارى عند النطاق الحرارى (323-553).

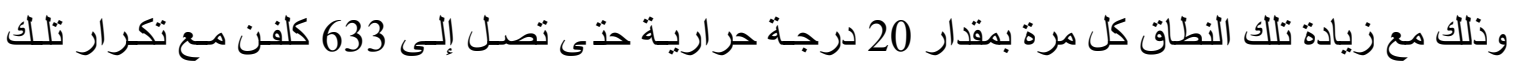

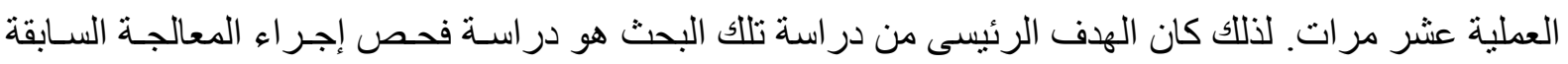
لمادة الليثيوم فلور ايد التى تم تطبيقها فى فئس [11]. 
من خلال شقين:

1- فحص تأثثير القر اءة لإشار ات الوميض الحرارى مع اختلاف مدى النطاق الحرارى المطبق. 2- فحص تأثثير الإستخدام المتكرر على عامل الحساسـية والعو امـل الحركيـة وذلك على كل قهـة مـن قمـ منحنى التو هج الحر ارى و أيضا على المساحة الكلية تحت المنحنى. وتضمنت النتائج أن فى حالة القر اءة عند نطاق درجات الحر ارة (323-553) كلفن أن القمـة الخامسـة هـى

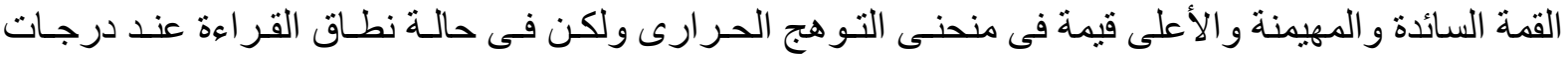
الحرارة (323-633) كلفن تصبح منطقـة الحـر ارة العاليـة جـا لمنحنـى التـوهج الحـر ارى هـى المنطقة السـائدة

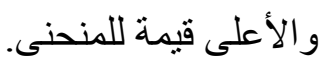

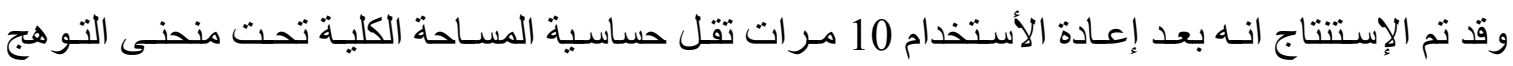
الحر ارى لمادة الليثيوم فلور ايد المعالجة بمقدار 0.6 وذلك لجميع حالات القر اءة لإشار ات الوميض الحرارى عنــ نطاق درجات الحرارة المختلفة ماعدا حساسية منطقة القر اءة لإشار ات الوميض الحر ارى عند درجـات الحرارة للمدى( 633-323) كلفن لا تتأثر بعدد مرات الإستخدام.

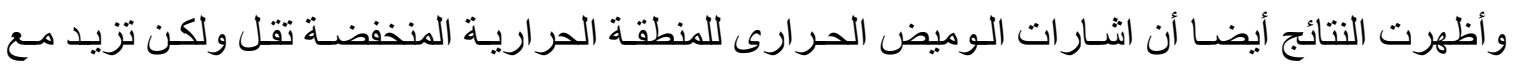
المنطقة الحر ارية العالية جدا وذلك نتيجة تأثثر إعادة الإستخدام مقاييس الجرعات عدة مرات. و أثبتت النتائج أيضا أن المساحة الكلية تحت منحنى التـوهج الحرارى تصبح مستقرة ومستقلة أيضـا بعد حوالى 7 مر ات من إعادة الإستخدام ولا تتاثر قيمتها أيضا بعد هذا الرقم من تكر ار الإستخدام. وقد بينت النتائج أيضا أنه فى حالة إعادة إستخدام مقاييس الليثيوم فلور ايد المعالجة قد تؤُثر على حساسيتها حتى فى ظل نفس الظروف التجريبية وهذا عندما لاتشمل القراءة الكلية لإشار ات الوميض الحرارى نطاق قراءة التهاة المنطقة الحر ارية العالية لمنحنى التو هج الحرارى وذللك عندما تكون درجة الحر ارة النهائية للقر اعة أكبر من 505

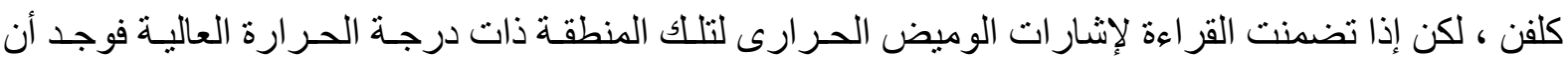
إثـار ات الوميض الحر ارى لمنطقة الحر ارة العالية جدا تزيد بشكل كبير مـع زيـادة عدد إعـادة إستخدام مقاييس الجر عات حتى تصل إلى 7 مر ات تصبح تللك المنطقـة مسـتقرة وموثوقـة تقريبـا للإسـتخدام فـى قيـاس الجر عـات الإشعاعية.

لذللك يوصى عند القر اءة بأن تكون درجة الحر ارة النهائية للقياس تقترب او اكبر من 633 كلفن لتشمل منطقة إثار ات الوميض الحر ارى لدرجات الحر ارة العالية لمقاييس الليثيوم فلور ايد المعالجة حيث ان تللك المنطقة تظل ديل ثابتة مع الأستخدام المتكرر عدة مرات.

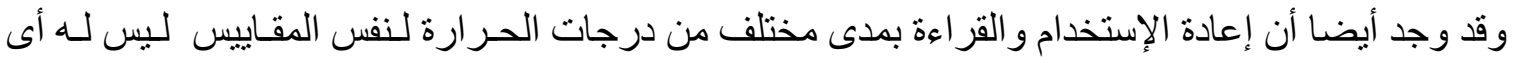

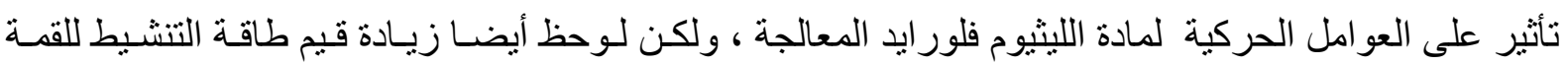
الخامسة من قمم منحنى التو هج الحرارى و هذه الزيادة ليست بسسب اختلاف مدى نطاق درجات الحـرارة لقراءة إثار ات الوميض الحر ارى ولا بسبب عدد مرات إعادة الإستخدام ولكن ترجع الزيادة إلى عملية المعالجة المطبقة على مادة الليثيوم فلور ايد و التى تم ذكر ها من قبل. 
